\title{
Roasted fox nuts (Euryale Ferox L.) contain higher concentration of phenolics, flavonoids, minerals and antioxidants, and exhibit lower Glycemic Index (Gl) in human subjects
}

\author{
Marrium Liaquat ${ }^{*}$ (D) Imran Pasha, Muhammad Ahsin and Abdullah Salik
}

\begin{abstract}
Fox nut (Euryale ferox) is categorized among superior quality foods because of its highly nutritious profile. It also serves as a good protein source for vegetarian diets. However, it is not widely consumed, due to soggy texture and bland flavor as compared to other nuts. In this study, we used roasting and seasoning to enhance its consumer acceptance. Furthermore, we have also compared biochemical, nutritional and physical properties of the roasted and unroasted fox nuts; and their Glycemic Index (Gl) in human subjects. Results showed that roasting significantly $(P \leq 0.05)$ improved the minerals content (from 0.58 to $0.66 \%$ ), protein content (from 11.40 to $14.57 \%$ ), total phenolics (from 346.02 to $470.62 \mathrm{mg} \mathrm{GAE} / 100 \mathrm{~g}$ ), flavonoids (from 4.15 to $4.43 \mathrm{mg}$ CE/g), 2,2-diphenyl-1picrylhydrazyl (DPPH) radical scavenging activity (from 48.54 to $79.13 \%$ inhibition) and Ferric Reducing Antioxidant Power (from 662.46 to $957.14 \mu \mathrm{mol} \mathrm{FeSO} / \mathrm{g}$ ). Consumer acceptance was evaluated with and without seasoning; both salt and spice seasoned roasted nuts had greater overall acceptability as compared to plain roasted and unroasted nuts. Fox nuts also reported low Gl (37\%) in human subjects (ethical approval \#1772/01-06-2020). Thus, roasted fox nuts can be consumed as nutrient rich and low Gl snack; not only as a component of healthy diet but can also be served to patients with metabolic disorders like obesity and diabetes.
\end{abstract}

Keywords: Euryale ferox seeds, Fox nuts, Roasting, Nutritious snack and low glycemic index foods

\section{Introduction}

Euryale ferox is an important cash crop of aquatic origin. It belongs to family Nymphaeaceae and is known worldwide with various names like "fox nut", "gorgon nut", "prickly water lily" and in the native language of Indian Sub-continent as "Makhana" or "Phool Makhana" (Goren-Inbar et al. 2014). Some scientists have referred Makhana seeds as "Black Diamonds" and "Black Gems of Wetlands" because of their black outer seed coat

\footnotetext{
* Correspondence: marium.liaquat1@gmail.com

National Institute of Food Science and Technology, Faculty of Food,

Nutrition and Home Sciences, University of Agriculture, Faisalabad 38000, Pakistan
}

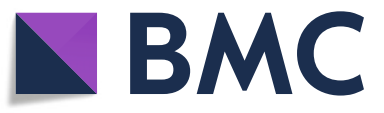

( The Author(s). 2022 Open Access This article is licensed under a Creative Commons Attribution 4.0 International License, which permits use, sharing, adaptation, distribution and reproduction in any medium or format, as long as you give

appropriate credit to the original author(s) and the source, provide a link to the Creative Commons licence, and indicate if changes were made. The images or other third party material in this article are included in the article's Creative Commons licence, unless indicated otherwise in a credit line to the material. If material is not included in the article's Creative Commons licence and your intended use is not permitted by statutory regulation or exceeds the permitted use, you will need to obtain permission directly from the copyright holder. To view a copy of this licence, visit http://creativecommons.org/licenses/by/4.0/ seeds that are processed into white puffed nuts and are the main reason for the popularity of the plant. These nuts are highly nutritious and counted as a superior food item in dry fruit category, based on its high Essential Amino Acid Index (EAAI) of 89-93\% (Kumar et al. 2011). It makes them an amazing reserve of essential amino acids which are not synthesized in the human body, and need to be part of diet.

Non-Communicable Diseases (NCDs) constitute a prime issue around the globe. The main reason behind their rapid prevalence is globalization and westernization of lifestyle and a dramatic shift and liking towards the 
consumption of processed and refined products (Korrapati et al. 2018). One of the coping strategies was presented long before by Dr. David Jenkins (1981) as a concept of Glycemic Index (GI) of foods, that could be used as a controllable factor for prevention of chronic diseases. Low GI foods have provided evidence for improving insulin sensitivity and fasting triglyceride levels along with maintenance in healthy body weight, and an appreciable improvement in health risk markers (Livesey et al. 2008). Fox nuts, being a low GI food, fits perfectly into the criteria of preferred foods for these Non-Communicable Diseases. Complex carbohydrate content of these nuts is responsible for low GI, and makes them an amazing snack for patients with NCDs. Nutrition therapy for diabetic patients by Canadian Diabetes Association has also included recommendations for foods having low glycemic index (Lawson et al. 2005).

Besides these nutritional properties, a wide range of medicinal properties of fox nuts has also been documented in ancient literature of Chinese and Indian medicine. Apart from its macro and micronutrients composition, it's the phenolic constituents and antioxidant properties, that impart specific medicinal attributes to fox nuts (Lee et al. 2002). Nuts rank third after spices and fruits for containing the most phytochemicals (Chang et al. 2016). Phenolic and flavonoid compounds are important determinants of the antioxidant activity, and overall nutritional quality of food stuff. Several studies have supported their role in managing human diseases (Lin et al. 2016). Antioxidant properties exhibited by the phenolic compounds are very much potent as compared to those of other nutrients (Shahidi \& Naczk 2003). Nuts are no doubt convenient and tasty snacks, and consuming one serving of nuts a day prevents the development of chronic diseases like cardiovascular disorders, type II diabetes, cancer, high blood pressure and neurodegenerative diseases (Chang et al. 2016). In addition to a bioactive-rich profile, fox nuts have higher concentration macro- $(\mathrm{Ca}, \mathrm{P}, \mathrm{K}, \mathrm{Na}$ and $\mathrm{Mg}$ ) and microminerals (Fe and $\mathrm{Zn}$ ) (Kumar et al. 2016).

The phytochemicals in nuts are affected by various factors like storage conditions, cultivars, plant location, and processing methods like roasting, irradiation, bleaching etc. (Bolling et al. 2011). Among these, roasting is a technique being used to improve these phytonutrients in food. It is widely being used for processing of nuts, to improve their nutritional quality and overall acceptability. Fox nuts, being soggy in texture, require roasting as a pretreatment to consumption. To gain maximum benefit from Euryale ferox: a wonder food, its phenolic and antioxidant profile needs to be preserved or enhanced during processing. The changes happening in the kernels when exposed to roasting include browning reactions like Maillard reaction or nonenzymatic browning (Mendes et al. 2001). These reactions are responsible for changes in color, texture, phenolic and antioxidant profile (Somporn et al. 2011).

The literature on numerous health benefits of fox nuts and its use in ancient medicines inform us to include this wonder food in our daily diet. Moreover, in comparison to other nuts, fox nuts contain a significantly lower fat content, which makes it a comparatively good choice. However, its high carbohydrate content raises concern whether fox nuts can be recommended to people with diabetes and other metabolic disorders. Soggy texture and bland taste also contributes to its limited consumption. The purpose of this study was to highlight the nutritional importance of fox nut as a low GI snack with additional benefits. There is little data on fox nuts in this regard. That is why, in addition to the GI study, we chose the parameters that contribute to consumer acceptance, which include minerals, phenolics, flavonoids, and antioxidant activity.

To the best of our knowledge, this study is the first one to introduce roasting and seasoning as a pretreatment to fox nuts' consumption to enhance consumer acceptability; and investigated possible compositional changes in roasted fox nuts. We also determined its glycemic index in human subjects to ensure if it could be consumed safely by people with diabetes and other metabolic issues. Salt and spice seasoned snacks were also prepared and evaluated for organoleptic properties.

\section{Materials and methods}

\section{Chemicals and reagents}

Nitric acid, perchloric acid, HPLC grade acetone, HPLC grade methanol, Folin-Ciocalteu reagent, sodium bicarbonate, gallic acid, sodium nitrite, aluminium chloride, sodium hydroxide, catechin, 2,2-diphenyl-1-picrylhydrazyl (DPPH), 2,4,6-tripyridyl-S-triazine (TPTZ), iron (III) chloride hexahydrate and iron (II) sulfate were purchased from Sigma (St. Louis, MO). Unless otherwise stated, all the reagents were of analytical grade and purchased from a certified vendor.

\section{Sample collection and roasting process}

Unroasted white puffed nuts were purchased from a grocery store at Faisalabad, Pakistan. A brief survey $(n=50)$ was conducted to ascertain consumer attitudes toward unroasted fox nuts as a potential snack. The most common attributes associated with consumer reluctance to consume this nut as a snack were its soggy texture and bland flavor (Data not given). For roasting, nuts were evenly distributed in a single layer over aluminium plate of preheated $\left(130 \pm 2{ }^{\circ} \mathrm{C}\right)$ hot air oven (UFB-400, Memmert, Germany) for $10 \mathrm{~min}$. After roasting, samples were 
allowed to cool at ambient temperature and packed in polythene zip bags until further analyses.

\section{Chemical compositional analysis}

The chemical composition of both unroasted (control) and roasted nuts was analyzed by approved methods of AOAC International (Latimer Jr. 2016). The moisture content was calculated by drying the samples in hot air oven at $105 \pm 2{ }^{\circ} \mathrm{C}$ (method no. 934-01). The moisturefree samples were completely burned on Bunsen burner followed by incineration in muffle furnace at $525^{\circ} \mathrm{C}$ for crude ash content (method no. 942-05). Nitrogen content was determined and fixed conversion factor for nuts (5.30) was used for crude protein calculations (method no. 981-10). Crude fat was determined by method no. 920.39 (A) and crude fiber by method no. 978-10. Nitrogen-free extract also referred to as carbohydrate content was calculated by subtracting all the aboveretrieved fractions from 100 (Latimer Jr. 2016).

\section{Mineral analysis}

Samples were wet-digested by di-acid mixture $\left(\mathrm{HNO}_{3}\right.$ : $\mathrm{HClO}_{4}$ ) in ratio of 3:1, respectively. Digests were analyzed by Atomic Absorption Spectrophotometer (AA240, Varian, Australia) for minerals analysis (Estefan et al. 2013).

\section{Extraction of phytochemical compounds}

The ground samples were subjected to the solid-liquid extraction method (Bonoli et al. 2004) with some modifications. Briefly, $4 \mathrm{~g}$ of the sample was allowed to interact with $40 \mathrm{~mL}$ of acetone-water extraction mixture (4:1, $\mathrm{v} / \mathrm{v})$ for $3 \mathrm{~h}$ while agitation $(250 \mathrm{rpm})$ over an orbital shaker (KS-260, Kika-Werke, Germany) followed by 30 min sonication (E60H. Elma, Germany) at $30^{\circ} \mathrm{C}$. The supernatant was harvested and residues were again treated with the fresh extraction mixture as discussed above. The supernatants were reconstituted and centrifuged at $1000 \mathrm{~g}$ for $10 \mathrm{~min}$. The solvent was evaporated from samples by rotary evaporator at low temperature $\left(-40{ }^{\circ} \mathrm{C}\right)$ and reduced pressure $(\mathrm{EV} 311 \mathrm{H}$, LabTech, China) near to dryness. Residues were reconstituted in 4 $\mathrm{mL}(1 \mathrm{~mL} / \mathrm{g}$ ground sample) HPLC grade methanol.

\section{Determination of total phenolic content (TPC)}

The phenolic content was determined by FolinCiocalteu method (Sharma et al. 2017). About $0.5 \mathrm{~mL}$ extract aliquot was mixed with $0.5 \mathrm{~mL}$ of Folin-Ciocalteu reagent and volume was raised to $9.5 \mathrm{~mL}$ by distilled water. After $3 \mathrm{~min}, 1 \mathrm{~mL}$ of $25 \%$ sodium bicarbonate was added to the reaction mixtures and incubated for $60 \mathrm{~min}$ at $25^{\circ} \mathrm{C}$, and absorbance was measured by UV-Vis Spectrophotometer (U2020, IRMECO, Germany) at $725 \mathrm{~nm}$. The results for TPC were calculated against the standard curve for gallic acid and results are expressed as mg of gallic acid equivalent (GAE) per $100 \mathrm{~g}$ of sample.

\section{Determination of total flavonoid content (TFC)}

Total flavonoid content was evaluated by following the protocol given (Rebaya et al. 2015). For each sample, about $125 \mu \mathrm{L}$ of methanolic extract was allowed to react with $75 \mu \mathrm{L}$ of sodium nitrite ( $5 \% \mathrm{w} / \mathrm{v}$ ) for $6 \mathrm{~min}$ followed by the addition of $150 \mu \mathrm{L} \mathrm{AlCl} 3(10 \% \mathrm{w} / \mathrm{v})$. After $5 \mathrm{~min}$ incubation, $750 \mu \mathrm{L} \mathrm{NaOH}(1 \mathrm{M})$ was added to each sample, and volume was raised to $2.5 \mathrm{~mL}$ by distilled water. The final incubation time was $\sim 15 \mathrm{~min}$ and absorbance was measured at $510 \mathrm{~nm}$ by UV-Vis Spectrophotometer. The results are expressed in $\mathrm{mg}$ catechin equivalent (CE) per gram of sample.

\section{Antioxidant analysis \\ Determination of DPPH radical scavenging activity}

Stable free radicals of 2,2-diphenyl-1-picrylhydrazyl $(\mathrm{DPPH})$ were used to evaluate the free radical scavenging antioxidant properties of the extracts. DPPH solution $(0.1 \mathrm{mM})$ was prepared by mixing $3.94 \mathrm{mg} \mathrm{DPPH}$ reagent in $100 \mathrm{~mL}$ HPLC grade methanol. About $150 \mu \mathrm{L}$ of methanolic extract was manually homogenized with 2 $\mathrm{mL}$ of DPPH solution. Homogenized samples were incubated for $30 \mathrm{~min}$ and absorbance was measured at 515 $\mathrm{nm}$ by UV-Vis Spectrophotometer (Prado et al., 2013).

\section{Determination of ferric reducing antioxidant power (FRAP)}

Ferric reducing antioxidant power of extracts was quantified as reported (Benzie \& Strain 1996). Fresh regent (FRAP) was prepared by mixing 2,4,6-tripyridyl-S-triazine $(10 \mathrm{mM}$ in $40 \mathrm{mM} \mathrm{HCl}), \mathrm{FeCl}_{3}: 6 \mathrm{H}_{2} \mathrm{O}(30 \mathrm{mM})$, and acetate buffer $(300 \mathrm{mM}, \mathrm{pH} 3.6)$ in the ratio 1:1:10, respectively. The solution was placed in a water bath at $37^{\circ} \mathrm{C}$ for $3 \mathrm{~h}$. Afterwards, $300 \mu \mathrm{L}$ methanolic extract volume was raised to $480 \mu \mathrm{L}$ by distilled water and allowed to react with $1.8 \mathrm{~mL}$ of FRAP reagent for $4 \mathrm{~min}$ at $37^{\circ} \mathrm{C}$. Absorbance was measured at $593 \mathrm{~nm}$ by a UV-Vis Spectrophotometer and results are expressed in $\mu \mathrm{M} \mathrm{FeSO}$ per gram sample.

\section{Color analysis}

The color analysis of nuts was performed by a colorimeter (Minolta, Milton Keynes, UK). Samples were evenly spread on a white surface and the instrument was calibrated by D65 illuminant. Results were obtained in the chromaticity coordinate $\left(\mathrm{L}^{*}, \mathrm{a}^{*}\right.$ and $\mathrm{b}^{*}$ ) values (Hojjati et al. 2015; Shakerardekani et al. 2011).

\section{Texture analysis}

Roasting impact on firmness (hardness) of the nuts was quantified by a texture analyzer (TA-XT2, Plus, Stable 
Microsystems, Surrey, UK) equipped with Ottawa cell HDP/90 arm (Piga et al. 2005).

\section{Bulk and calorie density analysis}

Bulk density of nuts was measured by filling a cylinder of known volume with nuts and removing excess kernels by a scale after tapping the cylinder twice (Kumar et al. 2013). The results were calculated by following expression:

$$
\rho \mathrm{b}(\mathrm{kg} / \mathrm{m} 3)=\frac{\text { Total mass of seeds }}{\text { Total volume of seeds }}
$$

Calorie density was calculated according to the Atwater general system for energy content of foods, based on energy-yielding substrates, regardless of the food type (Capuano et al. 2018). Following expression was used to calculate the results:

$$
\begin{aligned}
& \text { Total energy content }(\mathrm{Kcal} / 100 \mathrm{~g}) \\
& =(9 \times \% \text { fat })+(4 \times \% \text { protein }) \\
& +(4 \times \% \text { carbohydrate })
\end{aligned}
$$

\section{Study design for Glycemic Index trial}

The study was planned to compare the glucose responses of roasted fox nuts (test food) with glucose (reference food), both containing an equal amount of available carbohydrates $(25 \mathrm{~g})$. Blood glucose responses were monitored in human subjects in the morning, after overnight fasting of about $8 \mathrm{~h}$. The trial continued for a week, both (test and reference) foods were tested twice with a washout period of 2 days. The study was conducted at Nutrition and $\mathrm{Hi}$-Tech laboratory, University of Agriculture, Faisalabad.

\section{Recruitment of subjects}

Twenty-three healthy volunteer graduate students were contacted for the study and ten subjects were finally recruited, based on exclusion criteria (Fig. 1). Recruited human subjects were healthy adults (males $(n=5)$ and females $(\mathrm{n}=5)\}$ aged between 18 and 30 years with a normal Body Mass Index (BMI) $\left(19-25 \mathrm{~kg} / \mathrm{m}^{2}\right)$ and without any co-morbidity. Those engaged in shift works; having sleep disorders, impaired fasting blood glucose (>6 mmol/L), any metabolic disease, food allergy or hypersensitivity, smoking, or those taking any sort of medication that can interfere with carbohydrate metabolism, were excluded (Wolever et al. 2019). All the recruited participants had normal sleeping pattern $(7-9 \mathrm{~h}$ daily) and regular eating habits with a daily routine of having three proper meals and two snack meals. Eligibility was confirmed through an interview and screening session at the laboratory prior to inclusion. Written consent was taken from all the participants, informing them about the protocols, importance and harmlessness of the study.

\section{Determination of Glycemic Index}

International Standardization Organization's (ISO) developed standardized method for determining the glycemic index of food components was employed to quantify the glycemic index value (ISO 2010). Capillary blood (Finger prick samples) was analyzed for glucose estimation using Accu-Chek Active glucometer (Roche Diabetes Care, Inc. Chicago). Fasting blood glucose was monitored twice; $15 \mathrm{~min}$ and immediately prior to glucose consumption ( -15 and $0 \mathrm{~min})$. Glucose solution ( $25 \mathrm{~g}$ glucose in $250 \mathrm{~mL}$ water) was provided to the participants and blood samples were taken at 15, 30, 45, 60, 90 and $120 \mathrm{~min}$ after first sip of the drink. The same procedure was repeated for $33 \mathrm{~g}$ of fox nuts (containing $25 \mathrm{~g}$ of available carbohydrates) with $250 \mathrm{~mL}$ water.
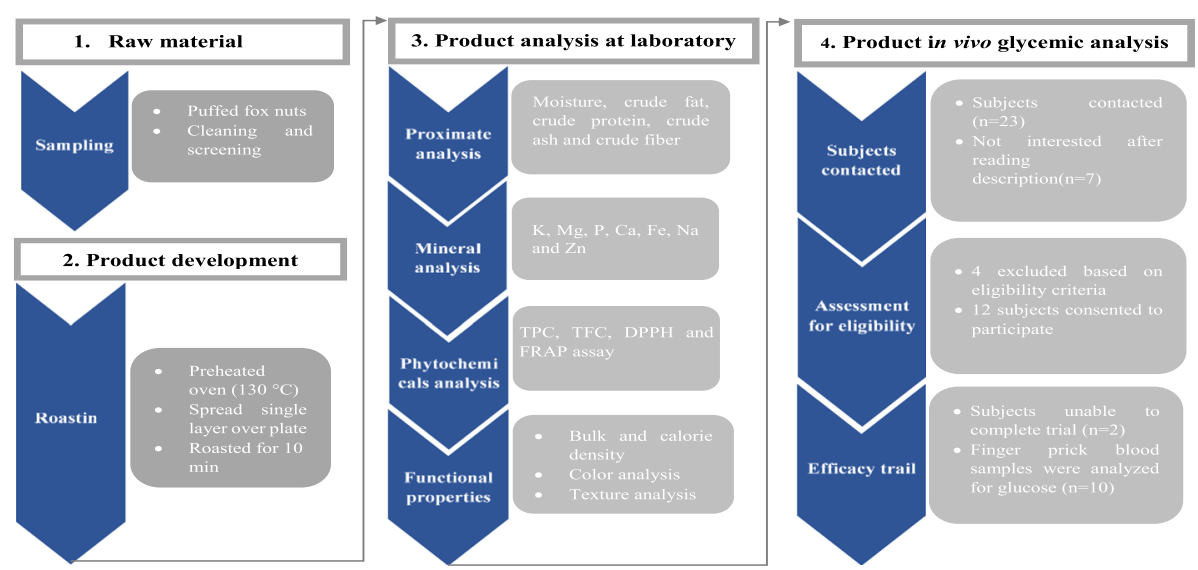

Fig. 1 Flow chart of study design showing all the major steps of methodology 
Incremental Area Under the Curve (iAUC) for glucose responses by both standard glucose solution and test food were computed as proposed by Food and Agriculture Organization (FAO 1998). Glycemic index was calculated by following expression:

$$
\mathrm{GI}(\%)=\frac{\text { iAUC for test food }}{\text { iAUC for reference food }} \times 100
$$

\section{Development and sensory evaluation of snacks}

Fox nuts were roasted $\left(130 \pm 2^{\circ} \mathrm{C}\right)$ and seasoned with different flavors and compared with control (unroasted and bland nuts) for various sensory attributes. A 9-point hedonic scale was used with scores ranging from 1 (dislike extremely) to 9 (like extremely). Twenty semitrained panelists consisting of post-graduate students and faculty members were briefed about the scoring system and sensory characteristics to be evaluated. They evaluated the snacks for their aroma, texture, flavor, crunchiness, bite strength and overall acceptability (Mehyar et al. 2012; Meilgaard et al. 2006).

\section{Analytical quality control and statistical analysis}

For quality control, samples were extracted/digested in duplicates (Vaux et al. 2012) with two sample blanks. Minerals (K, Mg, P, Ca, Fe, Na and $\mathrm{Zn}$ ) samples were run in triplicates on pre-calibrated Atomic Absorption Spectrophotometer (AA240, Varian, Australia). Mineral standards were purchased from Sigma (St. Louis, MO) and used for calibration of the equipment. Samples for proximates, TPC, TFC, DPPH, FRAP, color, texture and bulk density analysis were analyzed in triplicates. The results were expressed as mean values \pm standard deviation (SD).

Independent $\mathrm{T}$-test was used to measure the impact of roasting on chemical composition, minerals content $(\mathrm{K}$, $\mathrm{Mg}, \mathrm{P}, \mathrm{Ca}, \mathrm{Fe}, \mathrm{Na}$ and $\mathrm{Zn}$ ), TPC, TFC, DPPH, FRAP, color values $\left(\mathrm{L}^{*}, \mathrm{a}^{*}\right.$, and $\left.\mathrm{b}^{*}\right)$, texture, bulk density and calorie density. $P \leq 0.05$ was set for statistical significance. Analysis of variance (ANOVA) test was used to measure the effect of roasting and seasoning on sensory attributes of fox nut snacks; means were ranked by Tukey's Honestly Significant Difference (HSD) test $(P \leq$ $0.05)$. All the statistical analyses were performed on software IBM-SPSS Statistics for Windows (Version 23.0. Armonk, NY: IBM Corp).

\section{Results and discussion}

\section{Changes in chemical and mineral composition of fox nuts} by roasting

Fox nuts exhibit a nutritious profile that significantly enhanced upon roasting (Table 1). Roasted nuts contained significantly lower moisture content (4.17\%) and higher
Table 1 Chemical composition of control (unroasted) and roasted fox nuts (\% dry basis)

\begin{tabular}{lll}
\hline Treatments & Control & Roasted \\
\hline Moisture & $12.07 \pm 0.21^{\mathrm{a}}$ & $4.17 \pm 0.15^{\mathrm{b}}$ \\
Crude Ash & $0.58 \pm 0.04^{\mathrm{b}}$ & $0.66 \pm 0.03^{\mathrm{a}}$ \\
Crude protein & $11.40 \pm 0.44^{\mathrm{b}}$ & $14.57 \pm 0.29^{\mathrm{a}}$ \\
Crude fat & $0.63 \pm 0.05^{\mathrm{b}}$ & $0.68 \pm 0.02^{\mathrm{a}}$ \\
Crude fiber & $0.41 \pm 0.01^{\mathrm{b}}$ & $0.51 \pm 0.02^{\mathrm{a}}$ \\
Nitrogen free extract & $74.91 \pm 0.95^{\mathrm{b}}$ & $79.41 \pm 0.82^{\mathrm{a}}$
\end{tabular}

Values are means $\pm \mathrm{SD}(n=3)$. Mean values sharing different superscripts in rows show significant difference between the variables based on Independent T-test at $P \leq 0.05$

crude protein $(14.57 \%)$, crude ash $(0.66 \%)$, crude fat $(0.68 \%)$ crude fiber $(0.51 \%)$ and nitrogen-free extract (79.41\%) as compared to control (unroasted nuts). This nutrient condensation is mainly due to moisture loss from roasted nuts (65\% as compared to control), when exposed to high temperature. Similar decline in moisture content to below $3 \%$ was also reported in pulses and nuts after roasting (Açar et al. 2009).

The crude protein content of nuts increased by $28 \%$ upon roasting (Table 1), which is comparable to the crude protein in walnuts, hazelnuts and pistachio nuts $(13.7-17.1 \%)$ and higher than that in chestnuts (3.5\%) (Kalogeropoulos et al. 2013). This rise imparts a lot to its health benefits, as protein rich diets are highly appreciated because of their satiating effect with moderate rise in blood glucose levels. Moreover, the protein content of fox nuts mainly consists of essential amino acids with Essential Amino Acid Index (EAAI) of 89\% (GorenInbar et al. 2014). This makes fox nuts a good source of protein for vegetarian diet. This increase in protein content of fox nuts upon roasting is also supporting the increase in almonds (3\%), peanuts (9\%) (Süvari et al. 2017), sunflower seeds (37\%) (Adesina 2019) and groundnuts (5\%) (Kumar et al. 2013) after roasting.

An increase of $14 \%$ in ash content was observed upon roasting of fox nuts (Table 1) which also supports the

Table 2 Mineral profile of both control (unroasted) and roasted fox nuts ( $\mu \mathrm{g} \mathrm{g}^{-1}$ on d.w. basis)

\begin{tabular}{lll}
\hline Minerals & Control & Roasted \\
\hline Potassium & $450 \pm 21^{\mathrm{b}}$ & $472 \pm 18^{\mathrm{a}}$ \\
Magnesium & $244 \pm 16^{\mathrm{b}}$ & $263 \pm 23^{\mathrm{a}}$ \\
Phosphorus & $530 \pm 28^{\mathrm{b}}$ & $564 \pm 31^{\mathrm{a}}$ \\
Calcium & $179 \pm 09^{\mathrm{b}}$ & $192 \pm 12^{\mathrm{a}}$ \\
Iron & $109 \pm 07^{\mathrm{b}}$ & $127 \pm 10^{\mathrm{a}}$ \\
Sodium & $220 \pm 11^{\mathrm{b}}$ & $238 \pm 14^{\mathrm{a}}$ \\
Zinc & $15 \pm 2^{\mathrm{b}}$ & $18 \pm 3^{\mathrm{a}}$ \\
\hline
\end{tabular}

Values are means \pm SD $(n=6)$. Mean values sharing different superscripts in rows show significant difference between the variables based on Independent T-test at $P \leq 0.05$ 
increase in ash content of almonds (5\%), peanuts (15\%) and sunflower seeds (7\%) upon roasting (Süvari et al. 2017). Significant rise in crude fat (8\%), fiber (24\%) and carbohydrate content (6\%) was also reported in fox nuts upon roasting, which is also in accordance with the trend observed during roasting of groundnuts (Kumar et al. 2013). Carbohydrate content in fox nuts is significantly greater than other nuts (11.2 to $29.3 \%$ ) which is a compositional compensation for a strikingly low fat content. As, fat content in different seeds and nuts ranges from 1.9 to $66.5 \%$ (Kalogeropoulos et al. 2013), fox nuts have comparatively lower fat $(0.63-0.68 \%)$, which makes it a better choice for snacks over other high fat nuts, and also a good option for weight loss and frequent snacking.

Minerals are the nutrients that don't provide us with energy but are still crucial for various physiological mechanisms. Mineral profile of fox nuts is not exactly similar to other nuts. We chose to analyze these minerals $(\mathrm{K}, \mathrm{Mg}, \mathrm{P}$, $\mathrm{Ca}, \mathrm{Fe}, \mathrm{Na}$ and $\mathrm{Zn}$ ) in fox nuts based on their greater importance in the scenario of mineral deficiencies in developing countries like Pakistan (Ahsin et al. 2020; Government of Pakistan 2018). Almonds, cashews, pistachios, walnuts and macadamia nuts contain significantly higher content of potassium (3680 to $10,250 \mu \mathrm{gg}^{-1}$ ), magnesium (1210 to $2920 \mu \mathrm{g} \mathrm{g}^{-1}$ ), phosphorus (188 to $5930 \mu \mathrm{g} \mathrm{g}^{-1}$ ) and calcium (370 to $2690 \mu \mathrm{g} \mathrm{g}^{-1}$ ) as compared to fox nuts. However, these nuts contain prominently lower concentration of iron (29.1 to $66.8 \mu \mathrm{g} \mathrm{g}^{-1}$ ) and sodium (10 to $120 \mu \mathrm{g} \mathrm{g}^{-1}$ ) in comparison to fox nuts. Whereas, $\mathrm{Zn}$ in fox nuts is somewhat around the range in other nuts (13 to $57 \mu \mathrm{g} \mathrm{g}^{-1}$ ) (Amarowicz et al., 2017). Roasted fox nuts reported significantly greater proportion of potassium $\left(472 \mu \mathrm{g} \mathrm{g}^{-1}\right)$, magnesium $\left(263 \mu \mathrm{g} \mathrm{g}^{-1}\right)$, phosphorus $\left(564 \mu \mathrm{gg}^{-1}\right)$, calcium $(192 \mu \mathrm{g}$ $\left.\mathrm{g}^{-1}\right)$, iron $\left(127 \mu \mathrm{gg}^{-1}\right)$, sodium $\left(238 \mu \mathrm{gg}^{-1}\right)$ and zinc $\left(18 \mu \mathrm{g} \mathrm{g}^{-1}\right)$ as compared to control (unroasted fox nuts) (Table 2). $\mathrm{K}$ and $\mathrm{Ca}$ present in fox nuts plays a vital role in maintaining cardiovascular health. Whereas, Ca along with $\mathrm{P}$ and $\mathrm{Mg}$ is important for bone mineralization and musculo-skeletal health. Increase in mineral profile of fox nuts ( $~ 5$ to $20 \%)$ after roasting is supported by increase in potassium (5\%) and phosphorus (7\%) in roasted groundnuts (Kumar et al. 2013) and calcium (36\%), magnesium (18\%), potassium (6\%) and phosphorus (15\%) in roasted brown sesame seeds (Tenyang et al. 2017). Therefore, consumption of fox nuts can contribute in combating micro nutrient deficiencies.

\section{Roasted fox nuts contain higher phytochemicals with enhanced antioxidant activity}

Fox nuts, in comparison to other nuts, exhibit higher total phenolics content (ranged from 346.02 to 470.62 $\mathrm{mg}$ GAE/100 g) than macadamias (46 mg GAE/100 g), cashews (137 mg GAE/100 g), brazil nuts (112 mg GAE/ $100 \mathrm{~g}$ ) and almonds (239 mg GAE/100 g). However, pistachios (867 mg GAE/100 g) and walnuts (1625 mg GAE/100 g) reported an opposite trend (Kornsteiner et al. 2006). Whereas, the fox nuts' flavonoids content (4.43 $\mathrm{mg} \mathrm{CE} / \mathrm{g}$ ) was lower as compared to cashews (5.20 $\mathrm{mg} \mathrm{QE} / \mathrm{g})$, almonds (4.58 $\mathrm{mg} \mathrm{QE} / \mathrm{g}$ ) and pistachios (13.74 mg QE/g) (Ghazzawi \& Al-Ismail 2017). Roasting significantly affected the TPC and TFC of fox nuts, which ultimately altered the antioxidant activity exhibited by nuts after roasting (Fig. 2). TPC was 36\% higher in roasted nuts (470.62 $\mathrm{mg} \mathrm{GAE} / 100 \mathrm{~g}$ ) as compared to control (346.02 mg GAE/100 g). Similar increase in TFC (7\%) was also reported in roasted nuts as compared to control (4.15 mg CE/g) \{Fig. 2(a,b)\}. When we compare roasted fox nuts with other nuts in terms of antioxidant activity, it exhibits higher ability to scavenge DPPH free radicals (79.13\%), as compared to roasted cashews (59.99\%), pistachios (74.20\%) and almonds (78.1\%) (Ghazzawi \& Al-Ismail 2017). In conclusion, total phenols and flavonoids are variable among different nuts but roasted fox nuts exhibit higher antioxidant capacity than most of the widely consumed nuts (i.e., cashews, pistachios, and pistachios).

The increase in TPC, TFC, DPPH and FRAP profile of roasted fox nuts was found to be significant, which might be due to release of bound phenolics and flavonoids or making the available phenolics more extractable and assayable (Duodu 2014). The heat applied to foods of plant origin causes evaporation of intracellular water, which triggers various chemical reactions and promotes protein denaturation resulting in greater availability of plant phenolics in the matrix (Rizki et al. 2015). A variety of byproducts and brown pigments (melanoidins) are also produced when amino acids and reducing sugars react at high temperature (maillard reaction). These Maillard Reaction Products (MRPs) contribute to the phenolic content of roasted product, exhibit high antioxidant activity and cause flavor changes; and also contributed to a significant increase in the antioxidant activity of cashew nuts' skin and kernels upon roasting (Chandrasekara \& Shahidi 2011). Most of these products exhibit phenol or flavonoid like structures and are detected by the chemical reagents used in the analysis (Şahin et al. 2009). Melanoidins produced from these maillard reactions also improves the oxidative stability, aroma and flavor of oils extracted from roasted nuts (Suri et al. 2019).

Furthermore, the total antioxidant activity after roasting is the net activity exhibited by both the naturally occurring antioxidant compounds and newly formed Maillard reaction products. Therefore, roasting can affect both the nutritional and bioactive characteristics of foods (Rizki et al. 2015). The findings of this study supports increase in total antioxidant activity of cashew nuts (up to 60\%) after roasting, in contrast to other nuts. This increase was reported due to greater amount of starch 

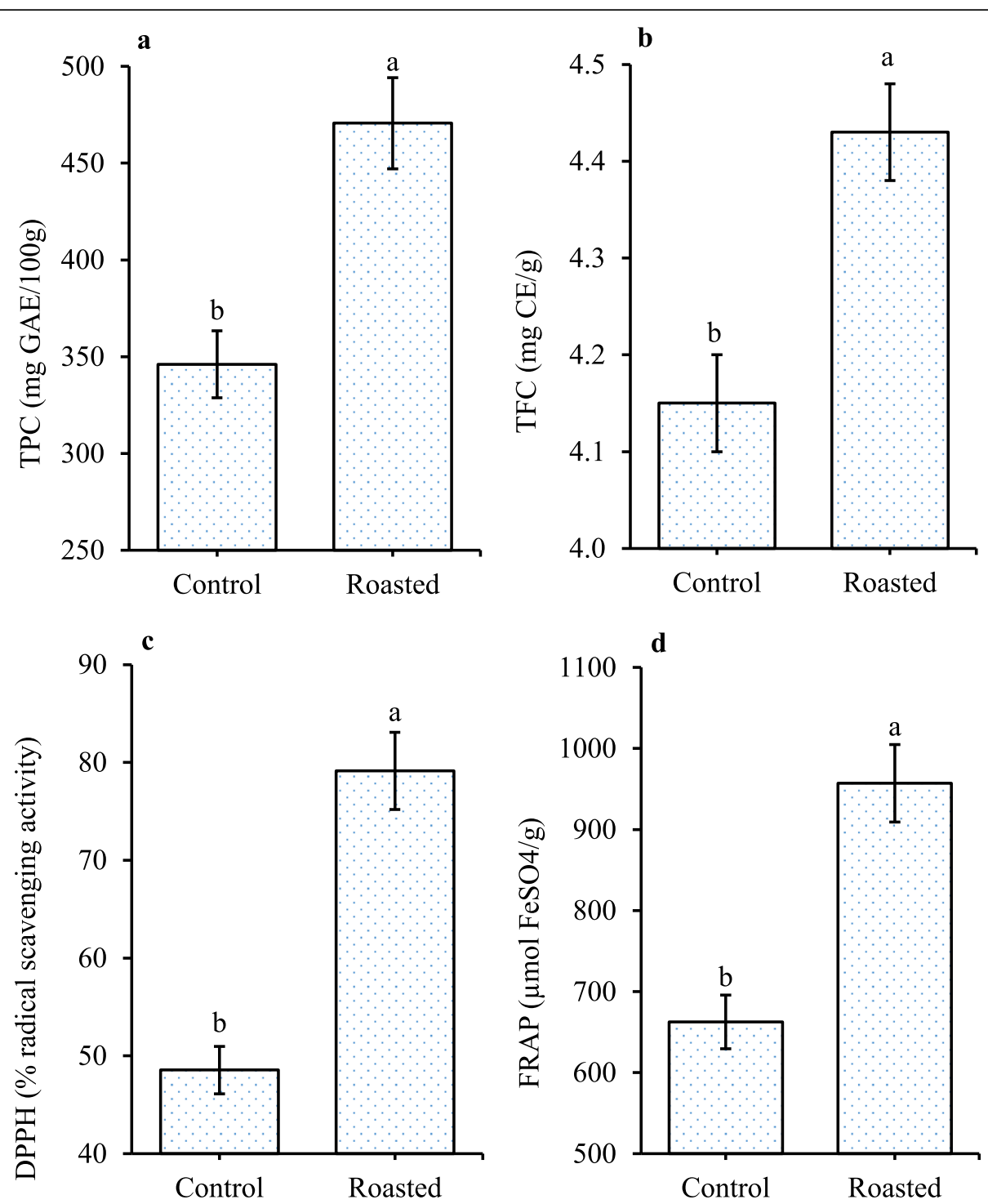

Fig. 2 Evaluation of the impact of roasting on phytochemicals and antioxidant capacity of fox nuts. a) Total phenolic content (TPC), b) Total flavonoid content (TFC), c) DPPH \% radical scavenging activity, d) FRAP activity. Values are mean of 6 replications; error bars stand for standard deviation. Means sharing different letters show significant difference between the variables based on Independent T-test at $P \leq 0.05$

(23\%) in cashew nuts, as compared to almonds $(0.74 \%)$, hazelnuts $(0.48 \%)$, pistachio $(1.67 \%)$ and pine nuts (1.43\%), which leads to formation of more antioxidant compounds through Maillard reactions (Açar et al. 2009).

\section{Impact of roasting on color and texture of fox nuts}

Significant $(P \leq 0.05)$ impact of roasting was observed on color and texture of fox nuts (Fig. 3). Color of the nuts was measured in terms of lightness $L^{*}$ and chromaticity co-ordinates $\mathrm{a}^{*}$ and $\mathrm{b}^{*}$. Color is one of the important characteristics of foods that attracts the consumer. Lightness $\left(L^{*}\right)$ was reported to be $45 \%$ lower in roasted nuts as compared to control (82.25), which is due to increase in brown color \{Fig. 3(a)\}. Similar decrease in $\mathrm{L}^{*}$ value (up to $41 \%$ ) was reported in corn kernels (Chung et al. 2014) due to increase in production of brown colored compounds with increase in temperature and time of roasting. Approximately, $12 \%$ decrease in $L^{*}$ value of pistachio nuts is also reported after roasting (Hojjati et al. 2015).

Roasted fox nuts showed 9\% decrease in $b^{*}$ value as compared to control (18.42) and $~ 400 \%$ higher red tint $\left(\mathrm{a}^{*}\right)$ than control (1.37) \{Fig. 3(b and c)\}. This increase in red tint occurred as a result of caramelization and browning reactions as reported in pistachio nuts ( $350 \%$ higher) after roasting (Hojjati et al. 2015). Similar increase in redness was also observed in corn kernels, ranging from 200 to $600 \%$ upon exposure to different roasting temperatures (Chung et al. 2014). 

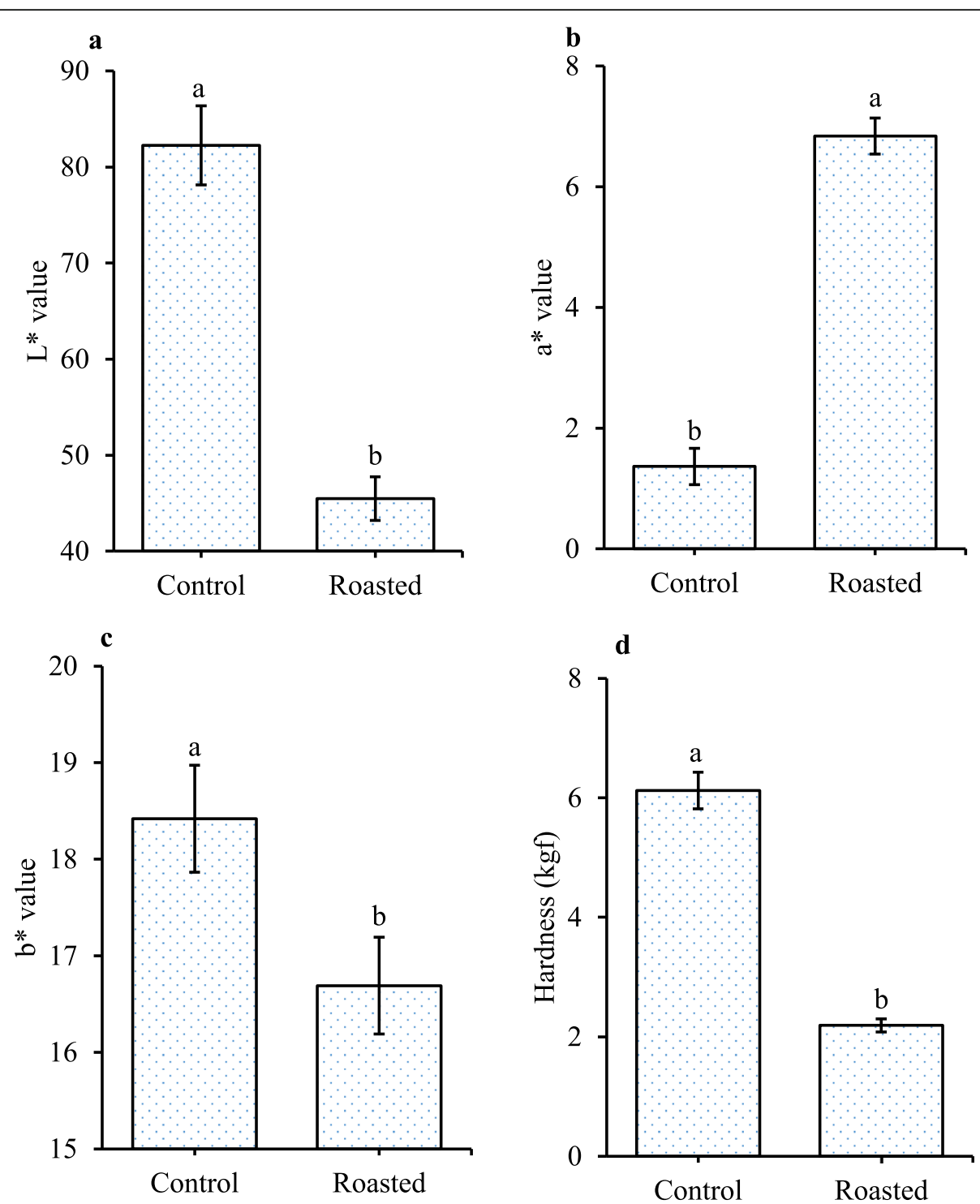

Fig. 3 Evaluation of the impact of roasting on physical characteristics of fox nuts. a) $L^{*}$ value for color, b) $a^{*}$ value for color, c) $b^{*}$ value for color, d) Hardness of nuts. Values are means of 6 replications; error bars stand for standard deviation. Means sharing different letters show significant difference between the variables based on Independent T-test at $P \leq 0.05$

A significant decline of $\sim 64 \%$ was noted in the force required to break the kernels after roasting \{Fig. $3(\mathrm{~d})$ \}. Means for hardness of nuts decreased from $6.12 \mathrm{kgf}$ to $2.19 \mathrm{kgf}$ upon roasting. This decrease in breaking force is due to increase in crispiness of fox nuts upon roasting. As moisture loss reduced its soggy texture and increased crispiness. Pistachio nuts also showed a decline (55\%) in hardness after roasting (Moghaddam et al. 2016). This declining trend is also in agreement with the findings for walnuts (Kita \& Figiel 2006) and pistachio nuts (Nikzadeh \& Sedaghat 2008), which confirms the use of roasting in decreasing the hardness of nuts.
Impact of roasting on bulk and calorie density of fox nuts Loss of moisture content in roasted nuts led to a $17 \%$ decrease in its bulk density \{Fig. 4(a)\}. Roasting significantly $(P \leq 0.05)$ decreased the bulk density of fox nuts from $100.30 \mathrm{~kg} / \mathrm{m}^{3}$ to $83.31 \mathrm{~kg} / \mathrm{m}^{3}$. The results were quite in accordance to literature (Jha \& Kachru 1998), which reported bulk density of makhana ranging from 70 to $90 \mathrm{~kg} / \mathrm{m}^{3}$ that varied with its moisture percentage. This decrease in bulk density was accompanied by a significant $(P \leq 0.05)$ rise $(\sim 9 \%)$ in calorie density from $350 \mathrm{kcal} / 100 \mathrm{~g}$ to $382 \mathrm{kcal} / 100 \mathrm{~g}$ after roasting \{Fig. 4(b)\}. Thus, equally weighed roasted nuts will give more calories as compared to unroasted ones. 


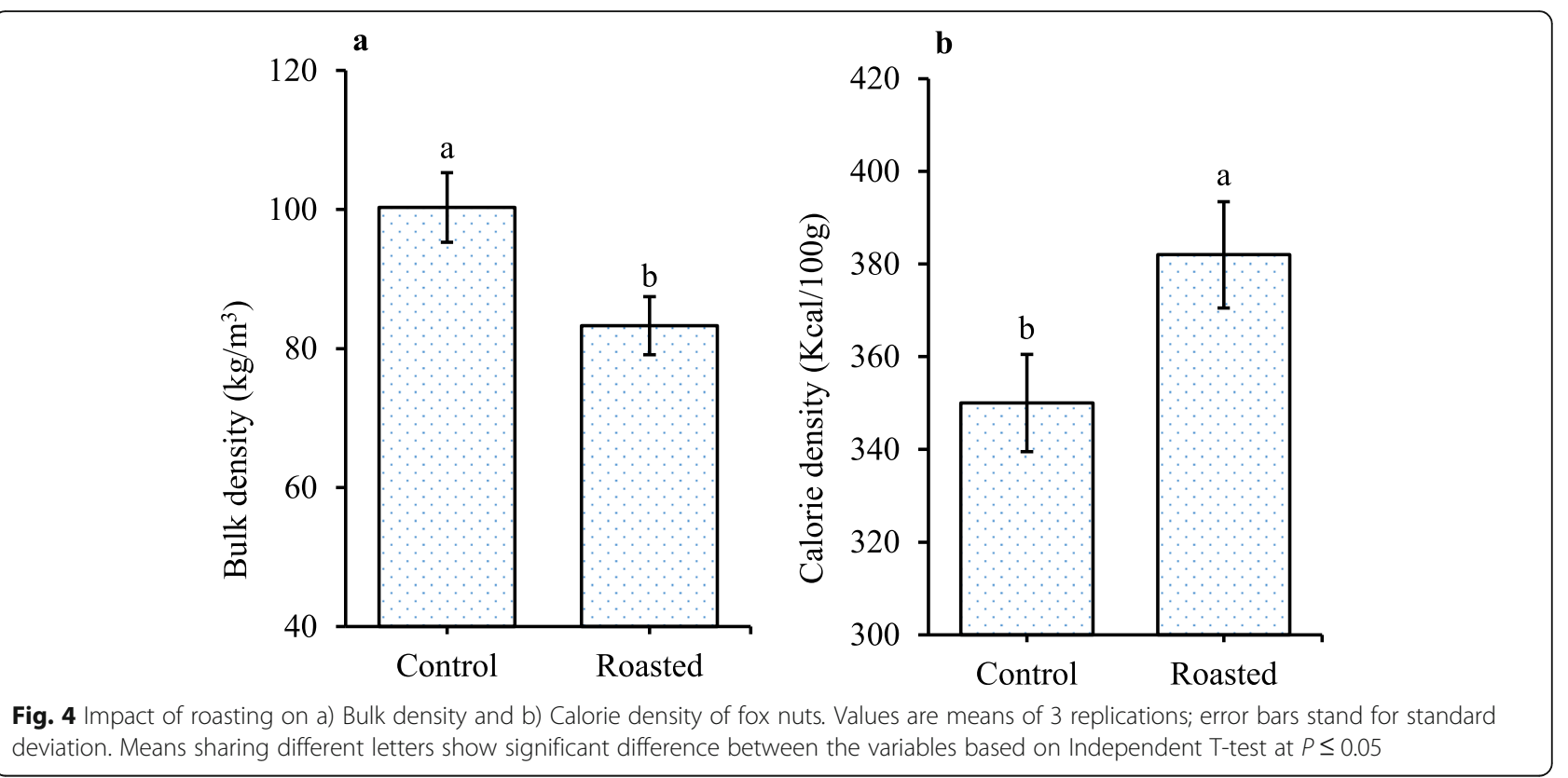

\section{Fox nuts exhibit low glycemic index (GI) in human subjects}

A positive correlation $\left(\mathrm{r}^{2}=0.81\right)$ was observed between GI and BMI of the participants (Table 3). Glycemic index of roasted fox nuts was $37.05 \%$. Incremental areas under the glucose response curve are presented for both test food (Fox nuts) and reference food (glucose powder), having an equal amount of available carbohydrates (Fig. 5). Based on GI, foods are classified into three categories; low GI foods $(\mathrm{GI}<55 \%)$, medium GI foods $(70 \%>\mathrm{GI}>55 \%)$ and high GI foods (GI > 70\%) (Widanagamage et al. 2009).

According to a recent systematic review on international tables of glycemic index values, nuts reported the lowest average GI values $(22 \pm 2)$ amongst all other food groups, because they constitute very low amount of carbohydrates (Atkinson et al. 2021). However, fox nuts make an exception as they contain comparatively higher carbohydrates and a higher GI, but still remain classified as low GI (37\%) snacks and ultimately preferable over other widely consumed moderate to high GI snacks like popcorns (55-89\%), potato crisps (57\%) jelly beans (80\%) and muesli bars (61\%) (Foster-Powell et al. 2002).

Table 3 Characteristics of participants $(n=10)$ enrolled and glycemic responses reported in glycemic index (Gl) study

\begin{tabular}{ll}
\hline Parameters & Values \\
\hline BMI $\left(\mathrm{kg} / \mathrm{m}^{2}\right)$ & $22.1 \pm 1.60$ \\
iAUC test food (mmol.min/L 2 h) & $86.30 \pm 6.74$ \\
iAUC reference food (mmol.min/L 2 h) & $232.67 \pm 6.41$ \\
Glycemic Index (\%) & $37.05 \pm 1.95$ \\
Glycemic Load & $9.26 \pm 0.49$ \\
\hline
\end{tabular}

Low GI foods have a potential beneficial impact on the prevention and management of metabolic syndrome (Livesey et al. 2008). Low GI foods are digested and absorbed slowly thus preventing a sudden rise in postprandial blood glucose levels. Apart from all these, low GI diets are also helpful in weight management and are in fact better than low-fat diets, as low GI diets are also associated with increasing the rate of resting energy metabolism (Pereira et al. 2004). Due to their slow digestion and absorption, foods with a low GI are associated with reduced hunger, increased satiety, decrease in voluntary food intake, reduction in insulinemia and ultimately promoting fat oxidation as a source of fuel for energy (Brand-Miller et al. 2009).

\section{Development and sensory evaluation of fox nuts snacks} In typical omnivorous diet, nuts and seeds are either consumed as snack items or added to savory and sweet dishes as minor ingredients, but they are widely consumed in vegetarian diets as important source of protein

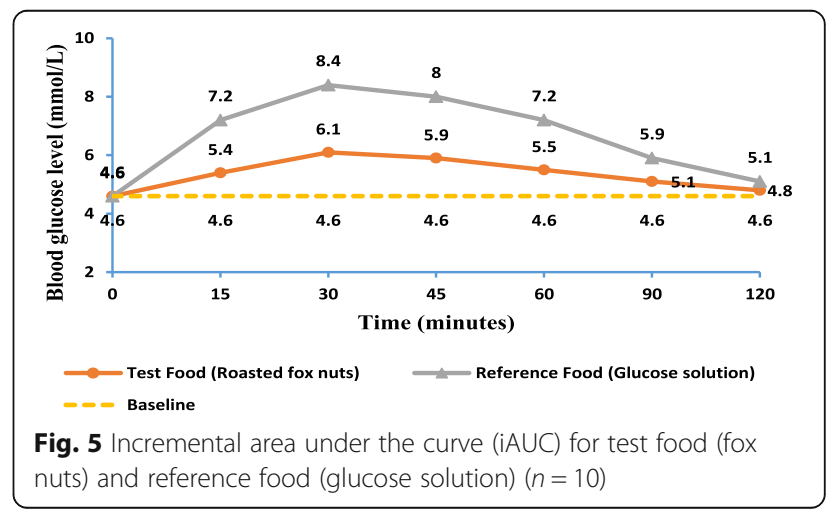




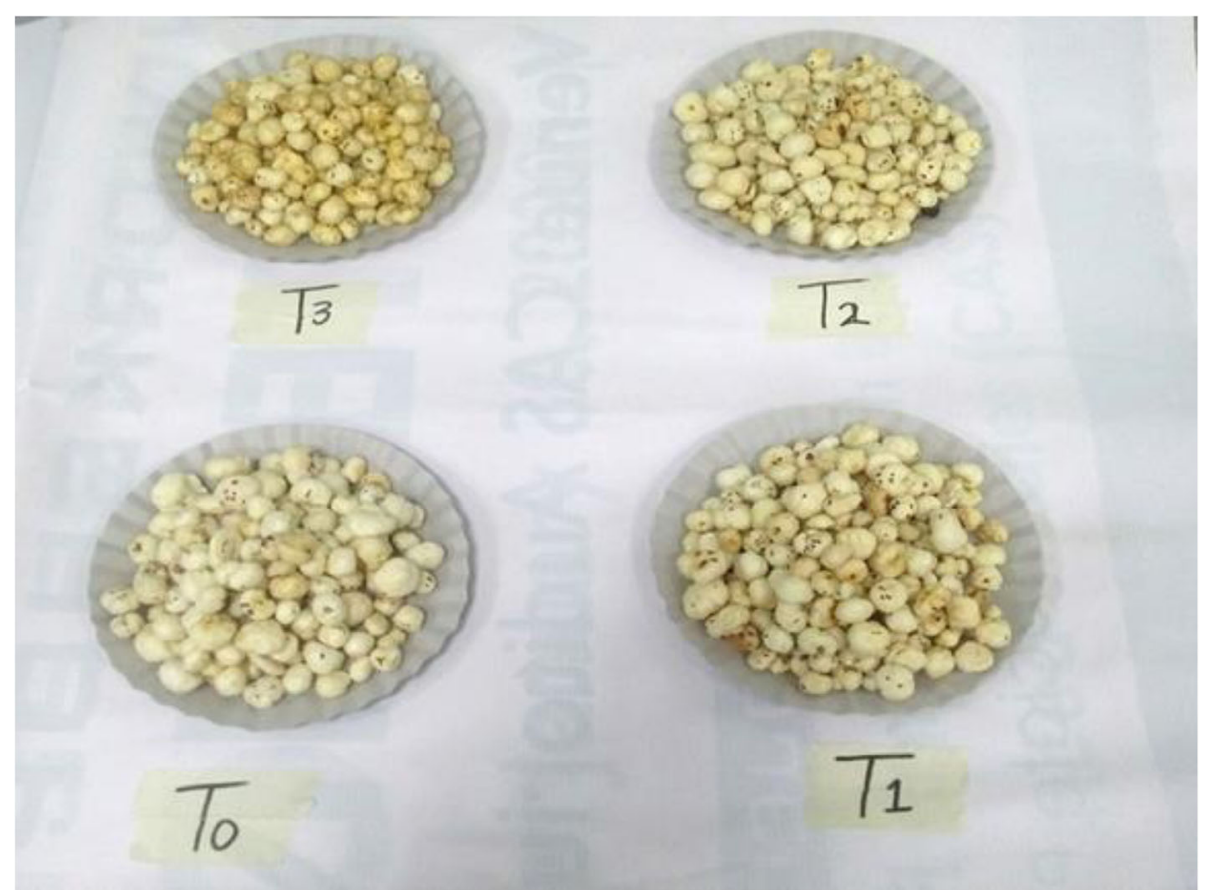

Fig. 6 Fox nuts snack treatments. $T_{0}=$ Unroasted; $T_{1}=$ Plain roasted; $T_{2}=$ Salt roasted; $T_{3}=$ Spice roasted

and other nutrients (Gray 2013). Fox nuts being high in protein, low in fat and low in GI offers numerous health benefits.

Fox nuts were seasoned with salt and spices (Fig. 6). Roasted nuts gained significantly $(P \leq 0.05)$ higher scores for aroma and texture after seasoning as compared to control and plain roasted samples. A significant $(P \leq 0.05)$ change was also observed among the flavor, crunchiness, bite strength and overall acceptability of the snacks (Table 4). Aroma (7.47), texture (7.74), flavor (7.68) and crunchiness (7.84) of spice roasted snacks were liked the most by consumers. The best response for bite strength (7.68) and overall acceptability (7.68) was observed for both salt and spice roasted nuts. Roasting improved the crunchiness $(82 \%)$, bite strength $(36 \%)$ and texture $(82 \%)$ of fox nuts with plain roasting leading to 23 times higher overall acceptability of nuts. Whereas, addition of salt and spice for seasoning improved the flavor (8\%) and overall acceptability (7\%) of fox nuts, in comparison to plain roasting.

\section{Conclusion}

The results shed light on the efficiency of roasting in making crispy and nutritionally superior product from raw fox nuts. Roasted fox nuts were figured out to contain higher phenolic and flavonoid content with enhanced antioxidant activity as compared to unroasted nuts. Roasting also increased the protein and mineral content of the nuts, thus increasing its nutrient density. High protein content of fox nuts also makes it a good source of protein for vegetarian diet. Furthermore, the prominent outcome of the study is the low GI of fox nuts, which makes it a healthy and nutritious snack in comparison to other widely consumed processed and energy-dense snacks. Roasting with added salt and spice increased the consumer acceptability of the nuts. Thus it is concluded that roasted fox nuts are better alternative for widely used high-fat and high-calorie snacks. Its low GI offers various health benefits including reduced hunger, increased satiety and obesity management. Hence it

Table 4 Mean values for sensory attributes of fox nuts snack treatments

\begin{tabular}{|c|c|c|c|c|c|c|}
\hline Treatments & Aroma & Texture & Flavor & Crunchiness & Bite Strength & Overall Acceptability \\
\hline$\overline{\mathrm{T}_{0}}$ & $6.37 \pm 1.42^{b}$ & $5.84 \pm 2.14^{b}$ & $5.58 \pm 1.92^{b}$ & $4.10 \pm 2.42^{b}$ & $5.47 \pm 2.22^{b}$ & $5.84 \pm 1.64^{b}$ \\
\hline $\mathrm{T}_{1}$ & $7.00 \pm 1.11^{\mathrm{ab}}$ & $7.32 \pm 1.29^{a}$ & $7.11 \pm 1.10^{\mathrm{a}}$ & $7.47 \pm 1.47^{a}$ & $7.42 \pm 1.07^{\mathrm{a}}$ & $7.16 \pm 0.96^{\mathrm{a}}$ \\
\hline $\mathbf{T}_{2}$ & $7.42 \pm 1.02^{\mathrm{a}}$ & $7.63 \pm 1.07^{\mathrm{a}}$ & $7.37 \pm 1.07^{\mathrm{a}}$ & $7.63 \pm 0.83^{\mathrm{a}}$ & $7.68 \pm 0.82^{a}$ & $7.68 \pm 1.00^{\mathrm{a}}$ \\
\hline$T_{3}$ & $7.47 \pm 0.90^{a}$ & $7.74 \pm 1.10^{\mathrm{a}}$ & $7.68 \pm 1.06^{\mathrm{a}}$ & $7.84 \pm 1.01^{\mathrm{a}}$ & $7.68 \pm 1.06^{\mathrm{a}}$ & $7.68 \pm 1.00^{\mathrm{a}}$ \\
\hline
\end{tabular}

Values are expressed as means \pm SD. Means sharing different superscripts along the columns are significantly different based on Tuckey's HSD test at $P \leq 0.05$. T0 $=$ Unroasted; $\mathrm{T} 1$ = Plain roasted; $\mathrm{T} 2$ = Salt roasted; $\mathrm{T} 3=$ Spice roasted 
is a safe and healthy option for vegetarians and those with metabolic disorders, as well as for general population as a healthy snack. Nutrition data of unroasted and roasted fox nuts derived from this research open new avenue for researchers to explore its prospective health benefits. A lot of research still needs to be done to explore its nutritional composition at a deeper level including the impact of roasting on amino acids, individual carbohydrates and characterization of flavor active compounds formed as a result of roasting.

\begin{abstract}
Abbreviations
GAE: Gallic acid equivalent; CE: Catechin equivalent; DPPH: 2,2-diphenyl-1picrylhydrazyl; FRAP: Ferric reducing antioxidant power; Gl: Glycemic Index; EAAl: Essential amino acid index; NCDs: Non-communicable diseases;" HPLC: High performance liquid chromatography; AOAC: Association of official analytical chemists; TPC: Total phenolic content; TFC: Total flavonoid content; BMI: Body mass index; ISO: International Standardization Organization; iAUC: incremental area under the curve; FAO: Food and agriculture organization.
\end{abstract}

\section{Acknowledgements}

This work is part of a master's thesis by Marrium Liaquat. We are thankful to all the graduate students and faculty members who volunteered for sensory evaluation and efficacy trial.

\section{Funding}

No funding was received to assist with the preparation of this manuscript.

\section{Authors' contributions}

$\mathrm{ML}, \mathrm{IP}$ and $\mathrm{AS}$ conceived and designed the study. ML and MA performed the experiments and worked on data analysis and interpretation. ML drafted the manuscript and all authors revised the manuscript and approved the final version to be submitted.

\section{Availability of data and materials}

All data generated or analysed during this study are included in this published article.

\section{Declarations}

\section{Ethical approval and consent to participate}

All the procedures followed for glycemic index study were according to the guidelines of National Biosafety Committee 2005 and Punjab Biosafety Rules 2014 and human ethical clearance was taken from Institutional Biosafety and Bioethics Committee (IBC) of University of Agriculture, Faisalabad, with protocol number 1772/01-06-2020. Informed consent was obtained from all individual participants included in the study.

\section{Consent for publication}

Not applicable.

\section{Competing interests}

The authors declare that they have no competing interests.

Received: 24 November 2021 Accepted: 26 December 2021 Published online: 18 January 2022

\section{References}

Açar, Ö. C., Gökmen, V., Pellegrini, N., \& Fogliano, V. (2009). Direct evaluation of the total antioxidant capacity of raw and roasted pulses, nuts and seeds. European Food Research and Technology, 229(6), 961-969. https://doi.org/10.1 007/s00217-009-1131-z.

Adesina, S. A. (2019). Effect of processing on the proximate composition of sunflower (Helianthus annuus) seeds. Agro-Science, 17(3), 27. https://doi.org/1 0.4314/as.v17i3.5.

Ahsin, M., Hussain, S., Rengel, Z., \& Amir, M. (2020). Zinc status and its requirement by rural adults consuming wheat from control or zinc-treated fields. Environmental Geochemistry and Health, 42(7), 1877-1892. https://doi. org/10.1007/s10653-019-00463-8.

Amarowicz, R., Gong, Y., \& Pegg, Ronald, B. (2017). Recent advances in our knowledge of the biological properties of nuts: functional food properties and applications. In Wild Plants, Mushrooms and Nuts: Functional Food Properties and Applications (377-407). https://doi.org/10.1002/9781118944653. ch11.

Atkinson, F. S., Brand-Miller, J. C., Foster-Powell, K., Buyken, A. E., \& Goletzke, J. (2021). International tables of glycemic index and glycemic load values 2021: A systematic review. The American Journal of Clinical Nutrition, 114(5), 16251632. https://doi.org/10.1093/ajcn/nqab233.

Benzie, I. F. F., \& Strain, J. J. (1996). The ferric reducing ability of plasma (FRAP) as a measure of "antioxidant power": The FRAP assay. Analytical Biochemistry, 239(1), 70-76. https://doi.org/10.1006/abio.1996.0292.

Bolling, B. W., Chen, C. Y. O., McKay, D. L., \& Blumberg, J. B. (2011). Tree nut phytochemicals: Composition, antioxidant capacity, bioactivity, impact factors. A systematic review of almonds, brazils, cashews, hazelnuts, macadamias, pecans, pine nuts, pistachios and walnuts. Nutrition Research Reviews, 24(2), 244-275. https://doi.org/10.1017/5095442241100014X.

Bonoli, M., Marconi, E., \& Caboni, M. F. (2004). Free and bound phenolic compounds in barley (Hordeum vulgare L.) flours: Evaluation of the extraction capability of different solvent mixtures and pressurized liquid methods by micellar electrokinetic chromatography and spectrophotometry. Journal of Chromatography A, 1057(1-2), 1-12. https://doi.org/10.1016/j. chroma.2004.09.024.

Brand-Miller, J., McMillan-Price, J., Steinbeck, K., \& Caterson, I. (2009). Dietary glycemic index: Health implications. Journal of the American College of Nutrition, 28(sup4), 446S-449S. https://doi.org/10.1080/07315724.2009.10718110.

Capuano, E., Oliviero, T., Fogliano, V., \& Pellegrini, N. (2018). Role of the food matrix and digestion on calculation of the actual energy content of food. Nutrition Reviews, 76(4), 274-289. https://doi.org/10.1093/NUTRIT/NUX072.

Chandrasekara, N., \& Shahidi, F. (2011). Effect of roasting on phenolic content and antioxidant activities of whole cashew nuts, kernels, and Testa. Journal of Agricultural and Food Chemistry, 59(9), 5006-5014. https://doi.org/10.1021/JF2 000772.

Chang, S. K., Alasalvar, C., Bolling, B. W., \& Shahidi, F. (2016). Nuts and their coproducts: The impact of processing (roasting) on phenolics, bioavailability, and health benefits - A comprehensive review. Journal of Functional Foods, 26, 88-122. https://doi.org/10.1016/j.jf.2016.06.029.

Chung, H. S., Kim, J. K., Moon, K. D., \& Youn, K. S. (2014). Changes in color parameters of corn kernels during roasting. Food Science and Biotechnology, 23(6), 1829-1835. https://doi.org/10.1007/s10068-014-0250-x.

Duodu, K. G. (2014). Effects of processing on phenolic phytochemicals in cereals and legumes. Cereal Foods World, 59(2), 64-70. https://doi.org/10.1094/CFW59-2-0064.

Estefan, G., Sommer, R., \& Ryan, J. (2013). Methods of soil, plant, and water analysis: A manual for the West Asia and North Africa region, (3rd ed.). Beirut: International Center for Agricultural Research in the dry areas (ICARDA).

FAO (1998). Carbohydrates in human nutrition. Report of an FAO/WHO Expert Consultation on Carbohydrates, April, 1997, 14-18.

Foster-Powell, K., Holt, S. H., \& Brand-Miller, J. C. (2002). International table of glycemic index and glycemic load values: 2002. The American Journal of Clinical Nutrition, 76(1), 5-56. https://doi.org/10.1093/ajcn/76.1.5.

Ghazzawi, H. A., \& Al-Ismail, K. (2017). A comprehensive study on the effect of roasting and frying on fatty acids profiles and antioxidant capacity of almonds, pine, cashew, and pistachio. Journal of Food Quality., 2017, 1-8. https://doi.org/10.1155/2017/9038257.

Goren-Inbar, N., Melamed, Y., Zohar, I., Akhilesh, K., \& Pappu, S. (2014). Beneath still waters - Multistage aquatic exploitation of Euryale ferox (Salisb.) during the Acheulian. Internet Archaeology, 37. https://doi.org/10.11141/ia.37.1.

Government of Pakistan. (2018). National Nutrition Survey 2018 - Key Findings Report | United Nations Children's Fund-Pakistan.

Gray, J. (2013). In Encyclopedia of human nutrition (Ed.), Nuts and seeds, (vol. 3-4, pp. 329-335). Elsevier. https://doi.org/10.1016/B978-0-12-375083-9.00208-7.

Hojjati, M., Noguera-Artiaga, L., Wojdyło, A., \& Carbonell-Barrachina, Á. A. (2015). Effects of microwave roasting on physicochemical properties of pistachios (Pistaciavera L.). Food Science and Biotechnology, 24(6), 1995-2001. https://doi. org/10.1007/s10068-015-0263-0.

ISO (2010). Food products - Determination of the glycaemic index (GI) and recommendation for food classification-ISO, 26642, 2010. https://www.iso. org/standard/43633.html. 
Jha, S. N., \& Kachru, R. P. (1998). Physical and aerodynamic properties of makhana. Journal of Food Process Engineering, 21(4), 301-316. https://doi.org/10.1111/j.1 745-4530.1998.tb00455.x.

Kalogeropoulos, N., Chiou, A., loannou, M. S., \& Karathanos, V. T. (2013). Nutritional evaluation and health promoting activities of nuts and seeds cultivated in Greece. International Journal of Food Sciences and Nutrition, 64(6), 757-767. https://doi.org/10.3109/09637486.2013.793298.

Kita, A., \& Figiel, A. (2006). The effect of roasting on the texture of walnuts. Acta Agrophysica, 7(1), 87-97.

Kornsteiner, M., Wagner, K. H., \& Elmadfa, I. (2006). Tocopherols and total phenolics in 10 different nut types. Food Chemistry, 98(2), 381-387. https:// doi.org/10.1016/j.foodchem.2005.07.033.

Korrapati, D., Jeyakumar, S. M., \& Katragadda, S. (2018). Development of low glycemic index foods and their glucose response in young healthy nondiabetic subjects. Preventive Nutrition and Food Science, 23(3), 181-188. https://doi.org/10.3746/pnf.2018.23.3.181.

Kumar, B., Sadagopan, R. S., Vasanthi, R. P. P., Kalapati, M., Vishnuvardhan, M., \& Purushotham (2013). Comparative physico-chemical, proximate and mineral analysis on raw and roasted seeds of groundnut. Communications in Plant Sciences, 3(June), 3-4.

Kumar, Lokender, Gupta, V.K., Jha, B.K., Singh, I.S., Bhatt, B.P., Singh A.K. (2011) Status of Makhana (Euryale ferox Salisb.) Cultivation in India, ICAR Research Complex for Eastern Region, Patna, Research Centre for Makhana, Darbhnga, Bihar-846005, India.

Kumar, L., Singh, A. K., \& Bhatt, B. P. (2016). Nutritional status of recently developed Makhana (Gorgon Nut) variety "Swarna Vaidehi". Journal of AgriSearch, 3(4). https://doi.org/10.21921/jas.v3i4.6701.

Latimer G. W. (2016). Official methods of analysis of AOAC international, In AOAC International (20th ed., Issue 2016).

Lawson, M., Pacaud, D., Lawrence, S., Daneman, D., \& Dean, H. (2005). 2003 Canadian clinical practice guidelines for the management of diabetes in children and adolescents Margaret. Pediatrics and Child Health, 10(Suppl A), 5A-16A. https://doi.org/10.1016/j.cnur.2017.07.008

Lee, S. E., Ju, E. M., \& Kim, J. H. (2002). Antioxidant activity of extracts from Euryale ferox seed. Experimental and Molecular Medicine, 34(2), 100-106. https://doi. org/10.1038/emm.2002.15

Lin, D., Xiao, M., Zhao, J., Li, Z., Xing, B., Li, X., ... Chen, S. (2016). An overview of plant phenolic compounds and their importance in human nutrition and Management of Type 2 diabetes. Molecules, 21(10), 1-19. https://doi.org/1 0.3390/molecules21101374.

Livesey, G., Taylor, R., Hulshof, T., \& Howlett, J. (2008). Glycemic response and health - A systematic review and meta-analysis: Relations between dietary glycemic properties and health outcomes. The American Journal of Clinical Nutrition, 87(1), 258S-268S. https://doi.org/10.1093/ajen/87.1.258s.

Mehyar, G. F., Al-Ismail, K., Han, J. H., \& Chee, G. W. (2012). Characterization of edible coatings consisting of pea starch, whey protein isolate, and carnauba wax and their effects on oil rancidity and sensory properties of walnuts and pine nuts. Journal of Food Science, 77(2), E52-E59. https://doi.org/10.1111/j.1 750-3841.2011.02559.x.

Meilgaard, M. C., Carr, B. T., \& Carr, B. T. (2006). Sensory Evaluation Techniques. CRC Press. https://doi.org/10.1201/b16452

Mendes, L. C., De Menezes, H. C., Aparecida, M., \& Da Silva, A. P. (2001). Optimization of the roasting of robusta coffee (C. canephora conillon) using acceptability tests and RSM. Food Quality and Preference, 12(2), 153-162. https://doi.org/10.1016/S0950-3293(00)00042-2.

Moghaddam, T. M., Seyed, Razavi, M. A., Taghizadeh, M., Sazgarnia, A. (2016). Sensory and instrumental texture assessment of roasted pistachio nut/kernel by partial least square (PLS) regression analysis: Effect of roasting conditions. Journal of Food Science and Technology, 53(1), 370-380. https://doi.org/10.1 007/s13197-015-2054-2

Nikzadeh, V., \& Sedaghat, N. (2008). Physical and sensory changes in pistachio nuts as affected by roasting temperature and storage. American-Eurasian Journal of Agricultural and Environmental Science, 4(4), 478-483.

Pereira, M. A., Swain, J., Goldfine, A. B., Rifai, N., \& Ludwig, D. S. (2004). Effects of a low-glycemic load diet on resting energy expenditure and heart disease risk factors during weight loss. Journal of the American Medical Association, 292(20), 2482-2490. https://doi.org/10.1001/jama.292.20.2482.

Piga, A., Catzeddu, P., Farris, S., Roggio, T., Sanguinetti, A., \& Scano, E. (2005) Texture evolution of "amaretti" cookies during storage. European Food Research and Technology, 221(3-4), 387-391. https://doi.org/10.1007/s00217005-1185-5.
Prado, A. C. P. do, Manion, B. A., Seetharaman, K., Deschamps, F. C., Barrera Arellano, D., \& Block, J. M. (2013). Relationship between antioxidant properties and chemical composition of the oil and the shell of pecan nuts [Caryaillinoinensis (Wangenh) C. Koch]. Industrial Crops and Products, 45, 6473. https://doi.org/10.1016/j.indcrop.2012.11.042.

Rebaya, A., Belghith, S. I., Baghdikian, B., Leddet, V. M., Mabrouki, F., Olivier, E., ... Ayadi, M. T. (2015). Total phenolic, Total flavonoid, tannin content, and antioxidant capacity of Halimium halimifolium (Cistaceae). Journal of Applied Pharmaceutical Science, 5(1), 052-057. https:/doi.org/10.7324/JAPS.2015.50110.

Rizki, H., Kzaiber, F., Elharfi, M., Ennahli, S., \& Hanine, H. (2015). Effects of roasting temperature and time on the physicochemical properties of sesame (Sesamum indicum .L) seeds. International Journal of Innovation and Applied Studies, 11(1), 148-155.

Şahin, H., Topuz, A., Pischetsrieder, M., \& Özdemir, F. (2009). Effect of roasting process on phenolic, antioxidant and browning properties of carob powder. European Food Research and Technology, 230(1), 155-161. https://doi.org/10.1 007/s00217-009-1152-7.

Shahidi, F., \& Naczk, M. (2003). Phenolics in food and nutraceuticals, (2nd ed., ). CRC Press. https://doi.org/10.1201/9780203508732.

Shakerardekani, A., Karim, R., Ghazali, H. M., \& Chin, N. L. (2011). Effect of roasting conditions on hardness, moisture content and colour of pistachio kernels. International Food Research Journal, 18, 723-729. https://doi.org/10.2139/ ssrn. 1799189.

Sharma, A., Joshi, N., Kumar, R. A., Agrawal, P. K., \& Prasad, S. (2017). High performance liquid chromatographic analysis of phenolic compounds and their antioxidant properties from different cultivars of Cyamopsis tetragonaloba (L.) Taub. Microchemical Journal, 133, 622-628. https://doi.org/1 0.1016/j.microc.2017.04.020.

Somporn, C., Kamtuo, A., Theerakulpisut, P., \& Siriamornpun, S. (2011). Effects of roasting degree on radical scavenging activity, phenolics and volatile compounds of Arabica coffee beans (Coffea arabica L. Cv. Catimor). International Journal of Food Science and Technology, 46(11), 2287-2296. https://doi.org/10.1111/j.1365-2621.2011.02748.x.

Sundaram, P. K., Sarkar, B., \& Mondal, S. (2014). Design and performance evaluation of pedal operated Makhana (Euryale ferox Salisb) seed grader. Research Journal of Agricultural Sciences, 5(3), 428-431.

Suri, K., Singh, B., Kaur, A., \& Singh, N. (2019). Impact of roasting and extraction methods on chemical properties, oxidative stability and Maillard reaction products of peanut oils. Journal of Food Science and Technology, 56(5), 24362445. https://doi.org/10.1007/S13197-019-03719-4.

Süvari, M., Sivri, G. T., \& Öksüz, Ö. (2017). Effect of different roasting temperatures on acrylamide formation of some different nuts. IOSR Journal of Environmental Science, Toxicology and Food Technology, 11(4), 38-43. https:// doi.org/10.9790/2402-1104013843.

Tenyang, N., Ponka, R., Tiencheu, B., Djikeng, F. T., Azmeera, T., Karuna, M. S. L., ... Womeni, H. M. (2017). Effects of boiling and roasting on proximate composition, lipid oxidation, fatty acid profile and mineral content of two sesame varieties commercialized and consumed in far-north region of Cameroon. Food Chemistry, 221, 1308-1316. https://doi.org/10.1016/j. foodchem.2016.11.025.

Vaux, D. L., Fidler, F., \& Cumming, G. (2012). Replicates and repeats-what is the difference and is it significant? A brief discussion of statistics and experimental design. EMBO Reports, 13(4), 291-296. https://doi.org/10.1038/ embor.2012.36.

Widanagamage, R. D., Ekanayake, S., \& Welihinda, J. (2009). Carbohydrate-rich foods: Glycaemic indices and the effect of constituent macronutrients. International journal of food sciences and nutrition, 60(sup4), 215-223. https:// doi.org/10.1080/09637480902849195.

Wolever, M., Jenkins, B.-M., Atkinson, G., Leuillet, C., Housez, \& Vinoy (2019). Glycemic index and Insulinemic index of foods: An Interlaboratory study using the ISO 2010 method. Nutrients, 11(9), 2218. https://doi.org/10.3390/ nu11092218

\section{Publisher's Note}

Springer Nature remains neutral with regard to jurisdictional claims in published maps and institutional affiliations. 